\title{
Penyuluhan tentang Kenali dan Waspada Corona Virus Diseases of 2019 (Covid-19) pada Acara Hari Bebas Kendaraan Bermotor Kota Padang
}

\author{
Russilawati, Irvan Medison, Afriani, dan Yessy Susanty Sabri \\ Fakultas Kedokteran, Universitas Andalas, Kampus Limau Manis, Padang, 25163. Indonesia \\ E-mail: russilawati@med.unand.ac.id
}

Keywords: cough etiquette, Covid-19, face mask, hand washing

Kata Kunci: cuci tangan, Covid-19, etika batuk, masker wajah

\begin{abstract}
Mysterious atypical pneumonia appeared abruptly in Wuhan, China in December 2019. China authority and Word Health Organization (WHO) found out the etiology on January 2020. New strain of Corona virus that eventually called by SARS-CoV2 has been responsible for the Corona virus disease of 2019 (Covid-19). The disease has ability to spread from human to human. These diseases had been pandemic since March 2020. As the start of early spreading we need to give right information about Covid-19 to the community so that the mass panicked could be avoided. We also need to educate community to take right precaution and prevention. These activities aims to spread the right information about Covid-19 and give simple training to performed prevention act so that community can slowdown the disease transmission. Methods: the campaign and health education about covid-19 and training of cough etiquette, right steps of hand washing using water and soap or alcohol based hand rub, and also how to use face mask properly. There were 66 participants that involved in this event. Participants had actively asked information about frequency of hand washing we need to prevent transmission and travel safety. We also performed flash mob so the participants could train cough etiquette, hand washing, and using face mask in fun ways. We ended the activities with competition of hand washing and using face mask properly. The door prize for the winner was hand sanitizer and face mask that they could use as tools to prevent transmission of Covid-19.
\end{abstract}
ABSTRAK
Pneumonia atipikal misterius muncul secara tidak terduga di Kota Wuhan, Cina pada Desember 2019. Pihak berwenang Cina dan Organisasi Kesehatan Dunia (WHO) menemukan etiologi pada Januari 2020. Starin baru virus korona yang pada akhirnya dinamakam SARS-CoV2 bertanggung jawab terhadap terjadinya Corona virus disease of 2019 (Covid-19). Penyakit ini mempunyai kemampuan menyebar dari manusia ke manusia lain. Penyakit ini juga telah dinyatakan menjadi pandemi sejak Maret 2020. Sejak penyebaran awal kita perlu memberikan informasi yang benar mengenai Covid-19 kepada masyarakat sehingga kepanikan massal bisa dihindari. Kita juga perlu mengedukasi masyarakat untuk mengambil langkah yang benar dalam kehati-hatian dan pencegahan. Kegiatan pengabdian ini bertujuan untuk menyebarkan informasi yang benar mengenai Covid-19 dan memberikan latihan sederhana kepada masyarakat untuk bisa melakukan tindakan pencegahan sehingga bisa memperlambat penyebaran penyakit. Metode yang dilakukan adalah kampanye dan penyuluhan kesehatan mengenai Covid-19 dan pelatihan mengenai etika batuk, langkah-langkah yang benar mencuci tangan dengan sabun atau cairan pembersih tangan berbasis alkohol, dan juga bagaimana memakai masker wajah dengan benar. Terdapat 66 pengunjung hari bebas kendaraan bermotor yang 
terlibat dalam acara ini. Peserta secara aktif menanyakan informasi mengenai frekuensi cuci tangan yang kita perlukan untuk mencegah penularan dan keamanan dalam melakukan perjalanan. Kami juga mengadakan flash mob sehingga peserta dapat berlatih etika batuk, cara cuci tangan dan memakai masker secara menyenangkan. Kami menutup acara pengabdian kepada masysrakat ini dengan lomba cuci tangan dan memakai masker wajah. Hadiah bagi pemenang adalah cairan pembersih tangan dan masker wajah yang bisa digunakan sebagai alat untuk mencegah penularan Covid-19.

\section{PENDAHULUAN}

Sejumlah kasus pneumonia yang secara klinis menyerupai pneumonia virus muncul di Wuhan China pada Desember 2019 (Huang, 2020). Virus yang diisolasi pada pasien-pasien tersebut tidak memiliki kesamaan dengan virus yang telah diketahui sebelumnya, yang dapat menyebabkan penyakit pada manusia. Kondisi ini mendapatkan perhatian penuh dari WHO, karena jika virus ini baru dikenal kita tidak tahu seberapa besar pengaruhnya terhadap manusia. (WHO, 2020). Otoritas China mengkonfirmasi pada tanggal 7 Januari 2020 bahwa mereka telah mengidentifikasi virus baru tersebut (WHO, 2020). Sel epitel dari saluran pernapasan manusia digunakan untuk mengisolasi coronavirus, yang pada awalnya disebut sebagai 2019-nCoV (Zhu, 2020). WHO pada tanggal 11 Februari 2020 secara resmi mengumumkan bahwa nama resmi untuk virus tersebut adalah Severe Acute Respiratory Syndrome-2 (SARS-CoV2) dan nama penyakitnya Corona virus disease of 2019 (Covid-19) (WHO, 2020). Virus ini berbeda dengan Middle East Respiratory Syndrome Coronavirus (MERS-CoV) dan Severe Acute Respiratory Syndrome (SARS-CoV) yang telah dikenal sebagai penyebab pneumonia virus berat dan menimbulkan outbreak pada tahun 2012 dan 2002 (Lu, 2020).

Penambahan jumlah kasus pneumonia 2019 nCoV/Covid-19 berlangsung cukup cepat dan sudah terjadi penyebaran ke luar wilayah Wuhan dan negara lain. Hingga 6 Februari 2020 angka kejadian Covid-19 sudah mencapai 20.630 kasus, dengan kematian 427 orang, di 25 negara. Diantara kasus tersebut sudah ada 80 orang tenaga kesehatan yang dilaporkan terinfeksi. Insiden ini semakin meningkat setiap harinya. WHO melaporkan bahwa penularan dari manusia ke manusia terbatas (pada kontak keluarga) telah dikonfirmasi di sebagian besar Kota Wuhan, China dan negara lain (WHO, 2020).

Manifestasi klinis biasanya muncul dalam 2 - 14 hari setelah paparan. Tanda dan gejala umum infeksi coronavirus antara lain gejala gangguan pernapasan akut seperti demam, batuk dan sesak napas. Hasil rontgen menunjukkan infiltrat pneumonia luas di kedua paru. Pada kasus yang berat dapat menyebabkan pneumonia, sindrom pernapasan akut, gagal organ, dan bahkan kematian (PDPI, 2020).

Menurut hasil penyelidikan awal, sebagian besar kasus di Wuhan memiliki riwayat bekerja, menangani, atau pengunjung yang sering berkunjung ke Pasar Grosir Makanan Laut Huanan (Huang, 2020). Penularan dari manusia ke manusia telah dikonfirmasi di Cina dan beberapa negara lain. Penularan terbatas diantara kontak dekat seperti kontak keluarga pasien terinfeksi dan petugas kesehatan. Risiko infeksi terbesar adalah orang-orang di Cina atau orang yang telah berpergian ke Cina maupun negara lain yang terdapat kasus Covid-19 (Fuk-Woo Chan, 2020).

Covid-19 merupakan penyakit yang baru dikenal. Penyebarannya yang cepat dan adanya indikasi penularan dari manusia ke manusia dapat menimbulkan kepanikan pada masyarakat. Meskipun fatality rate penyakit ini lebih rendah dibandingkan dengan wabah SARS dan MERS yang sama-sama disebabkan oleh Coronavirus namun penyebarannya lebih luas, sehingga jumlah absolut kematiannya lebih tinggi. Masyarakat luas harus mendapatkan informasi yang 
benar mengenai penyakit ini baik dalam hal gejala, pencegahan dan cara aman berpergian. Penyebaran informasi yang tidak benar akan menimbulkan kepanikan dan kerugian sosioekonomi yang harus ditanggung masyarakat. Pengetahuan mengenai pencegahan utama yang efektif sesuai anjuran WHO yaitu mencuci tangan dengan sabun dan air atau hand rub berbasis alkohol, dan etika batuk harus terus disosialisasikan. Demikian juga dengan edukasi mengenai perlunya memakai masker dan bagaimana cara memakai masker yang benar. Berdasarkan latar belakang tersebut, kami dari Bagian dan PPDS Pulmonologi dan Kedokteran Respirasi bekerjasama dengan bagian Promosi Kesehatan RSUP Dr. M. Djamil Padang melakukan kegiatan pengabdian masyarakat berupa promosi kesehatan dalam bentuk penyuluhan, dan interaksi langsung mengenai "Kenali dan Waspada Pneumonia 2019 n-Cov" di area Car Free Day Jalan Khatib Sulaiman Padang pada Minggu tanggal 9 Februari 2020.

\section{METODE}

Pelaksanaan kegiatan pengabdian masyarakat dan promosi kesehatan mengenai Pneumonia 2019-nCoV di Area Car Free Day Jalan Khatib Sulaiman Padang pada hari Minggu 9 Februari 2020. Bentuk-bentuk kegiatan berupa :

a) Kampanye Waspada Pneumonia Wuhan

b) Flashmob etika batuk dan cara cuci tangan yang benar oleh staf Pengajar, Peserta PPDS dan dokter muda Pulmonologi dan Kedokteran Respirasi dan Promkes RSUP. Dr.M. Djamil bersama dengan pengunjung Car Free Day Jalan Khatib Sulaiman Padang

c) Penyuluhan tentang "Kenali dan Waspada Covid-19/ Pneumonia 2019-nCoV"

d) Diskusi interaktif dengan pengunjung Car Free Day Jalan Khatib Sulaiman Padang

e) Edukasi etika batuk, cara cuci tangan dan pemakaian masker yang benar

f) Lomba pemasangan masker dan cara cuci tangan yang benar.

\section{HASIL DAN PEMBAHASAN}

Kegiatan pengabdian masyarakat ini dimulai dengan kampanye waspada pneumonia Wuhan atau Covid-19. Kampanye ini dilakukan dengan long march dari depan Masjid Raya Sumbar ke lokasi penyuluhan. Kampanye ini dilakukan dengan membawa spanduk dan peraga lain yang menjelaskan secara umum apakah Covid-19 tersebut. Kampanye juga mengajak pengunjung kegiatan hari bebas kendaraan bermotor untuk mengikuti acara-acara selanjutnya.

Acara selanjutnya adalah flashmob mengenai etika batuk yang benar. Kegitan ini secara menarik menjelaskan bagaimana etika batuk yang benar dengan cara yang menarik. Etika batuk yang benar yang disosialisasikan oleh Kementerian Kesehatan Republik Indonesia (Kemenkes RI) yaitu dengan memakai masker, menutup hidung dan mulut dengan lengan atas bagian dalam, menutup mulut dan hidung dengan tisu yang kemudian segera dibuang ke tong sampah tertutup dan jangan lupa mencuci tangan sesudahnya (Kemenkes RI, 2020).

Cara cuci tangan yang benar juga disosialisasikan dengan cara berjoget bersama. Langkahlangkah cuci tangan mengggunakan air dan sabun serta alternatifnya cairan pembersih tangan berbasis alkohol dilakukan dengan mengacu pada rekomendasi cara cuci tangan dari Kemenkes RI dan Organisasi Kesehatan Dunia (WHO). Langkah-langkah tersebut mencakup sebagai berikut;

1. basahi tangan dengan air bersih

2. gunakan sabun secukupnya

3. gosok telapak tangan yang satu ke telapak tangan lainnya

DOI: https://doi.org/10.25077/jwa.27.2.119-125.2020 
4. gosok punggung tangan dan sela jari

5. gosok telapak tangan dan sela jari dengan posisi saling bertautan

6. gosok punggung jari ke telapak tangan dengan posisi jari saling bertautan

7. genggam dan basuh ibu jari dengan posisi memutar

8. gosok bagian ujung jari ke telapak tangan agar bagian kuku terkena sabun

9. gosok tangan yang bersabun dengan air bersih mengalir

10. keringkan tangan dengan lap sekali pakai atau tissu

11. bersihkan pemutar keran air dengan lap sekali pakai atau tissu.

Mencuci tangan menggunakan cairan pembersih tangan dapat dilakukan dalam situasi tertentu di mana sabun dan air bersih tidak tersedia. Agar hasilnya efektif, cairan pembersih tangan yang digunakan hendaknya mengandung alkohol dengan kadar minimal 60\%. Untuk langkah cuci tangan dengan cairan pembersih tangan hanya mengikuti langkah 3-9 (Kemenkes RI, 2020; WHO, 2019).

Kegiatan penyuluhan diawali dengan pemberian materi pengenalan apakah itu Covid-19/ Pneumonia 2019-nCoV yang dilakukan oleh dr. Russilawati,SpP(K) dan dr Irvan Medison,SpP(K). Kami juga memperkenalkan etiologinya yaitu virus yang termasuk dalam golongan virus corona dan menjelaskan dengan bantuan gambar. Selanjutnya dijelaskan gejala-gejalanya yaitu demam, batuk, pilek, hilang penciuman, sesak napas dan mencret yang timbul dalam 14 hari setelah melakukan perjalanan ke daerah terjangkit (PDPI, 2020). Penjelasan lain termasuk juga penyebarannya yang saat itu episenter epideminya adalah kota Wuhan, Cina dan mulai menyebar ke Asia Tenggara (WHO, 2020).

Setelah penyuluhan dilanjutkan dengan diskusi dengan pengunjung yang ingin bertanya. Beberapa pertanyaan pengunjung antara mengenai sesering apa kita harus cuci tangan yang dojawab oleh narasumber sebaiknya sesering mungkin terutama setelah menyentuh bendabenda yang banyak disentuh oleh orang banyak seperti tombol lift, gagang pintu, remote televisi di kamar hotel dan lain-lain. Pengunjung lain menanyakan keamanan perjalanan untuk wisata bagi warga senior yang kemudian dijelaskan perlunya mengevaluasi adanya penyakit komorbid dan kerentanan karena usia lanjut pada peserta dan pertimbangan untuk menunda perjalanan.

Kami juga menjelaskan mengenai cara memakai masker yang benar sesuai rekomendasi Kemenkes RI. Penjelasan mencakup jenis-jenis masker, di mana digunakan dan juga peragaan mememakai masker. Rekomendasi saat itu adalah masker lebih diutamakan bagi tenaga kesehatan dan orang yang merawat orang sakit serta orang yang berada dilingkungan orang sakit seperti ruang tunggu rumah sakit (Kemenkes RI, 2020)

Untuk evaluasi dan menarik perhatian pengunjung kami mengadakan lomba peragaan mencuci tangan dan memakai masker yang benar. Perlombaan diikuti secara antusias oleh pengunjung. Peserta dari berbagai kelompok umur dan latar belakang. Dalam perlombaan ini kami memberikan hadiah berupa cairan pembersih tangan dan masker bagi peserta yang bisa melakukan dengan benar. Peserta dapat mengulang ikut kembali meskipun pada putaran awal gagal atau kurang sempurna dalam langkah mencuci tangan maupun memakai masker dengan demikian peserta dapat belajar sampai bisa melakukan dengan benar. Kami berharap peserta selanjutnya menjadi agen perubahan yang akan mensosialisasikan dua cara utama mengurangi penyebaran virus corona ini di lingkungan masing-masing. 

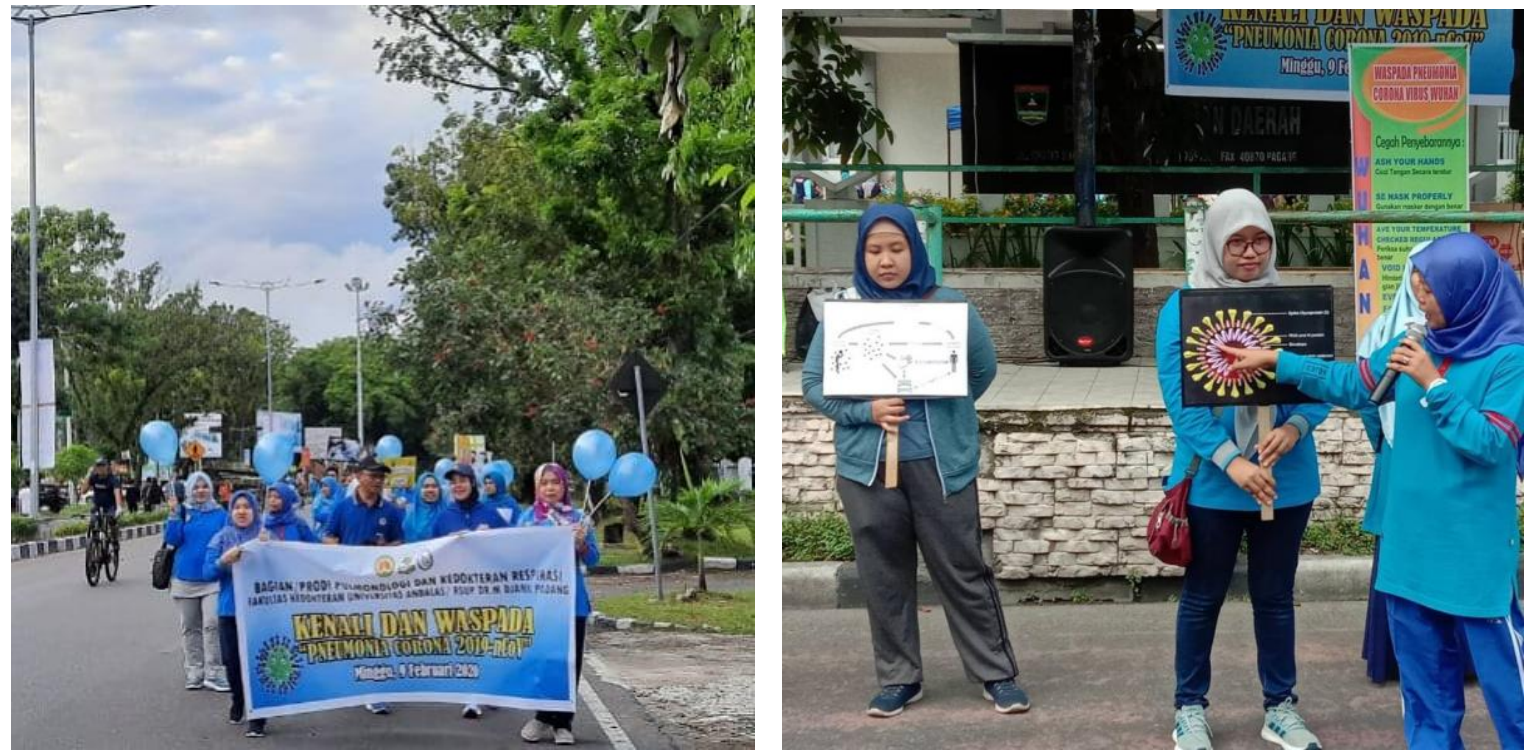

Gambar 1. Kampanye dan Penyuluhan Waspada Pneumonia Wuhan melalui Pola Hidup Sehat
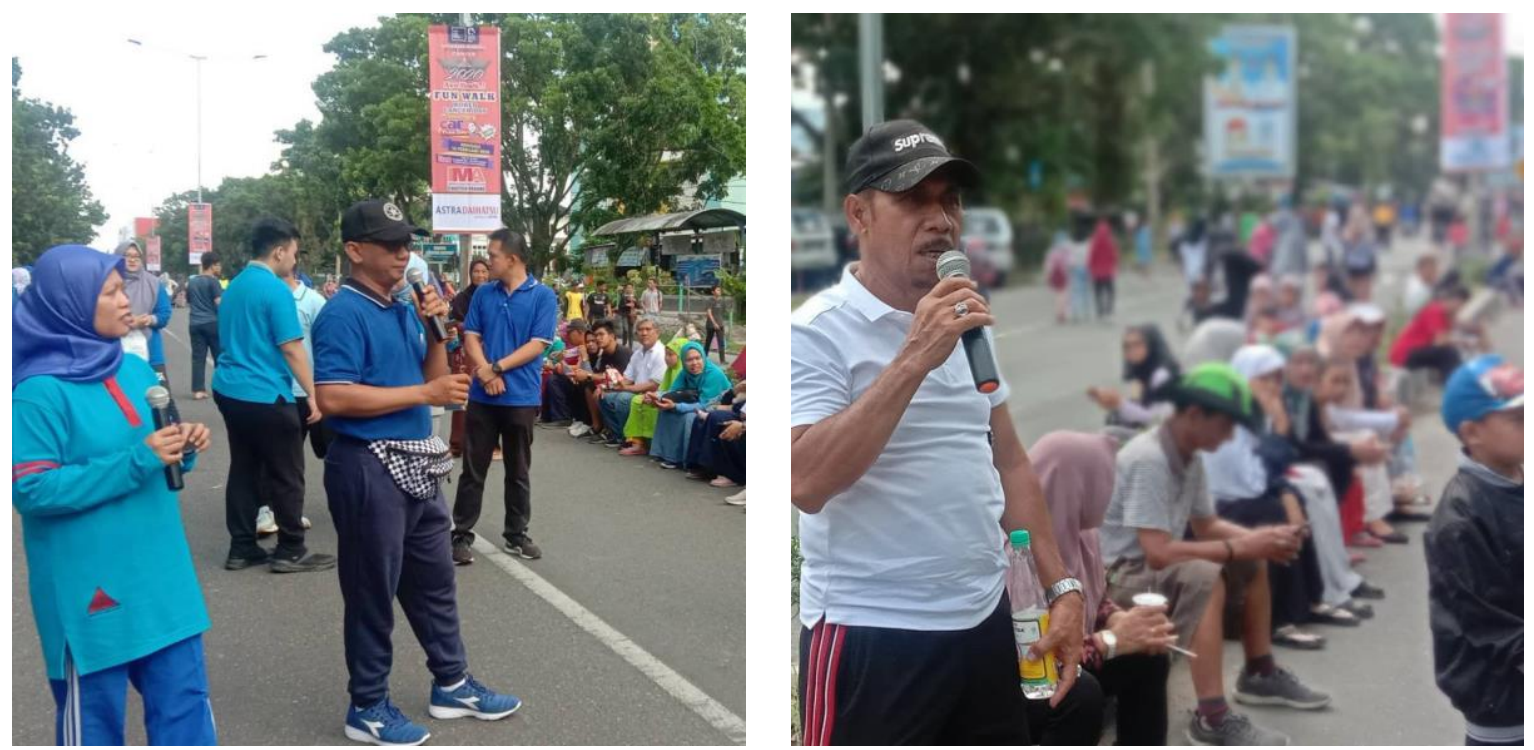

Gambar 2. Diskusi dengan peserta kegiatan
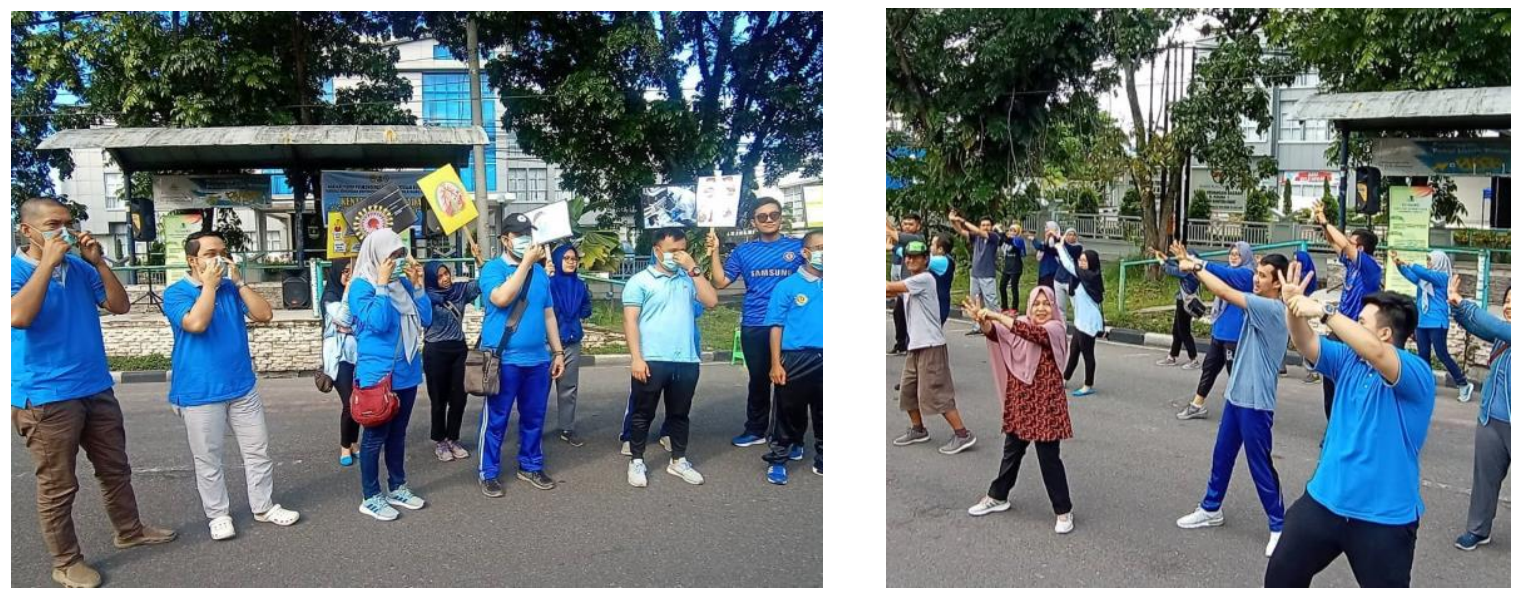

Gambar 3. Edukasi pemakaian masker yang benar dan Flashmob hand hiegine dan etika batuk 

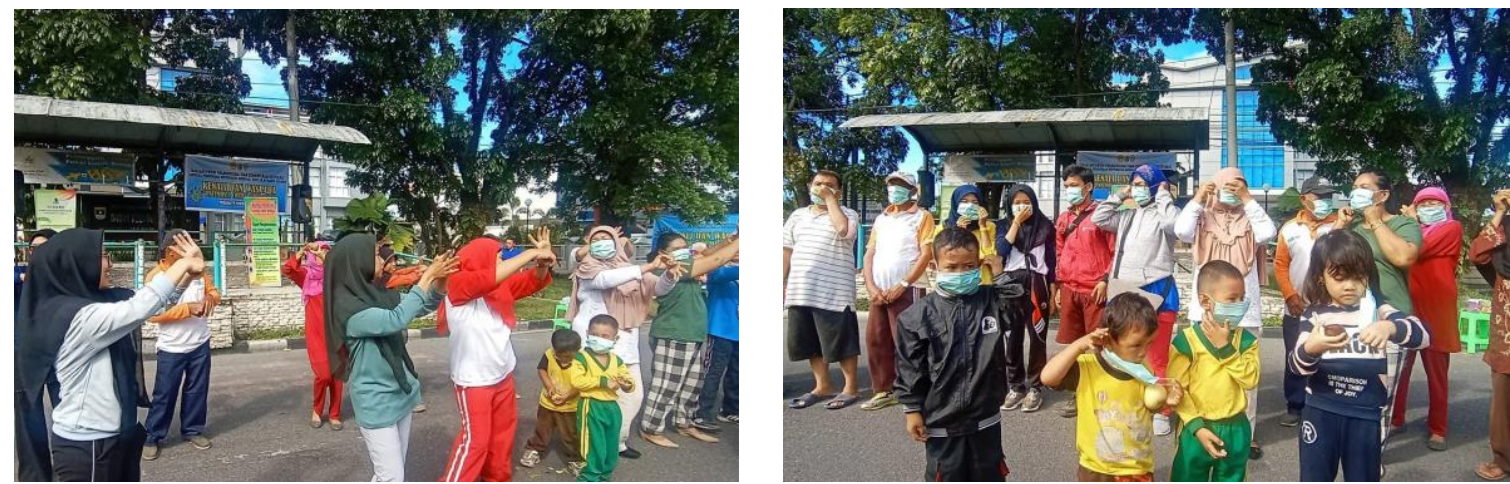

Gambar 7. Lomba hand higiene dan lomba pemakaian masker

\section{KESIMPULAN DAN SARAN}

Kegiatan pengabdian berupa promosi kesehatan ini perlu dilakukan sehingga masyarakat bisa mendapatkan informasi mengenai berbagai masalah kesehatan yang bisa mempengaruhi mereka dan cara antisipasinya. Covid-19 pada akhirnya menjadi pandemi yag mempengaruhi seluruh aspek kehidupan masyarakat dunia. Peran masyarakat dalam mengurangi laju penyebaran penyakit sangat penting. Masyarakat harus ditumbuhkan kesadarannya akan pentingnya mencuci tangan, memakai masker dan menjaga jarak atau menghindari pergi ke tempat berisiko tertular virus penyebab Covid-19.

\section{UCAPAN TERIMA KASIH}

Kegiatan pengabdian masyarakat ini terselenggara berkat kerja sama Bagian dan PPDS Pulmonologi dan Kedokteran Respirasi dengan bagian Promosi Kesehatan RSUP Dr. M. Djamil Padang. Kami juga mengucapkan terima kasih atas dukungan Perhimpunan Dokter Paru Indonesia Cabang Sumatera Barat (PDPI Sumbar).

\section{DAFTAR PUSTAKA}

Fuk-Woo Chan J, Yuan S, Kok K-H, Kai-Wang To K, Chu H, Yang J, et al. A familial cluster of pneumonia associated with the novel coronavirus indicating person to person transmission: a study of a family cluster. www.thelancet.com Publised online January 24, 2020 https://doi.org/10.1016/S0140-673(20)30154-9

Huang C, Wang Y, Li X, Ren L, Zhao J, Hu Y, et al. 2020. Clinical features of patients infected with 2019 novel coronavirus in Wuhan, China. The Lancet vol 395: 497-506.

Kemenkes RI. 2020. Flyer- Etika batuk. https://promkes.kemenkes.go.id/flyer-etike-batuk diakses 9 Desember 2020.

Kemenkes RI. 2020. Flyer- Cara memakai masker yang benar. https://promkes.kemkes.go,id/flyer-cara-memakai-masker-yang-benar-format-pdf 
Lu R, Zhao X, Li J, Niu P, Yang B, Wu H, et al. 2020. Genomic characterisation and epidemiology of 2019 novel coronavirus : implication for virus origins and receptor binding. The Lancet vol 395: 565-74

Perhimpunan Dokter Paru Indonesia(PDPI).2020. Pneumonia Covid-19. Diagnosis dan Penatalaksanaan di Indonesis. PDPI; Jakarta-Indonesia.

WHO. Novel Coronavirus (2019-nCoV) https://www.who.int/emergencies/diseases/novelcoronvirus-2019, diakses 14 Februari 2020 WHO. Novel Coronavirus(2019-nCoV) Situation Report - 17. Data as reported 6 February 2020.

WHO. 2019. Hand Hygiene: why, how and when?. Genewa-Swiss.

Zhu N, Zhang D, Wang W, Li X, Yang Bo, Song J, et al. 2020. A novel coronavirus from patients with pneumonia in China, 2019. The New England Journ of Medicine 382;8: 727-33. 